\title{
Los Grupos de Innovación Educativa GIE: Una alternativa válida para los Docentes Universitarios
}

\author{
PhD. Lauro Fernando Pesántez Avilés \\ Universidad Politécnica Salesiana, UPS \\ fpesantez@ups.edu.ec \\ Cuenca, Ecuador \\ https://orcid.org/0000-0003-1799-0795
}

\section{Editorial}

Las Instituciones de Educación Superior de América Latina no necesariamente han manejado un escenario de vanguardia en los procesos de la investigación científica, sea porque su tradición académica estuvo orientada, especialmente, al ámbito de la docencia o, porque se ha subestimado el potencial de sus claustros académicos para generar conocimiento $\mathrm{o}$, incluso, por las precarias fuentes de financiamiento que han soportado los proyectos universitarios, por lo que, históricamente, se ha privilegiado la enseñanza y la extensión sobre la investigación.

Sin embargo, de lo antes mencionado, no deja de ser verdad que, en más de una ocasión, los cuerpos docentes, muchas veces en solitario y con insuficientes estructuras de gestión universitaria, han solventado soluciones pertinentes a los desafíos que su entorno sociocultural les ha sabido requerir a título de la función investigación. Ante la dualidad presente, es necesario desmitificar aquellas lógicas que privilegian la visión de que la investigación solo puede ser gestada por aquellos con grandes dotes disciplinares o que es particular proceso de los que poseen un grado científico del más alto nivel.

Las diversas fórmulas de clasificación de la investigación nos dan una primera pauta para entender que la generación de saberes puros, son tan válidos como la aplicación de los vigentes; los modelos de creación o trasferencia no son mejores ni peores sino únicamente en función de sus resultados.

Por otro lado, hay que entender que las distintas ciencias abarcan 
múltiples disciplinas y entonces, la investigación unidisciplinaria es tan oportuna como la que aglutina diversas perspectivas epistémicas; asimismo, las clasificaciones por áreas, subáreas o dominios es tan amplia que cabe en ella todas las posibilidades. Por ende, no hay como despreciar ninguna tentativa investigativa, basta contar, como menciona Bunge (2004): con un problema que pueda ser tratado, que esté bien formulado, concebido y delimitado (pág. 166).

Es ahí, en el problema de investigación, donde se nutren las distintas posibilidades para que los docentes universitarios, sin excepción, consideren pasar de docentes a docentes-investigadores, en tal sentido, una propuesta universal para ello sería que los problemas de aprendizaje inherentes a la cátedra asignada a cada maestro se conviertan en el principal foco de investigación.

Los abordajes de dichas problemáticas pueden extenderse desde: el campo de la didáctica, la metodología y las técnicas de aprendizaje, la evaluación de saberes y del desempeño, las secuencias de aprendizaje, el uso de recursos didácticos incluyendo las tecnologías de información y comunicación, en definitiva, desde cada uno de los componentes del denominado diamante curricular se pueden ofrecer campos de investigación cuyo objeto de estudio sea la mejora de los aprendizajes. Por ello, la investigación educativa le es propicia a todo maestro, sin excepción de su nivel de formación o de sus habilidades científicas.

Como todo proceso en búsqueda de soluciones, ha de ser necesario plantearse correctamente los objetivos de investigación, y en el caso de lo educativo, estos resultan evidentes, más aún cuando las desigualdades sociales son determinantes en las llamadas fórmulas de acceso, permanencia y egreso exitoso que hasta ahora no resultan para nada efectivas en cada uno de los subsistemas de educación incluyendo el terciario. En definitiva, para Pesántez, Martín, Bojorque (2015): es una visión de igualdad en los diversos 
niveles de la trayectoria escolar, junto al acceso a los bienes culturales de las ciencias, las técnicas y las artes, en pos de enfrentar los desafíos de la educación superior, permite que emerjan las metas a alcanzar (pág. 63 -73).

Por tanto, contar a la par con Grupos de Investigación Científica GI y otros denominados Grupos de Innovación Educativa GIE, no solo es posible en el ambiente universitario, sino necesario para dinamizar la acción educativa, incluso es aún posible prescindir de los -GI- más no de los denominados GIE, ya que el primero de nuestros beneficiarios en ser atendido de manera científica ha de ser el propio alumno, en cuanto métodos de aprendizaje que le sean ofrecidos.

La historia de la universidad, por lo menos así la respalda, evidencia que por décadas la investigación científica fue incipiente en nuestra América, y se solventó el tema de desarrollo científico con la apropiación de saberes vía adquisición de textos, procesos de formación en el extranjero y hoy, con la consideración de que el conocimiento es global e interconectado, se podría mitigar de cierta forma la acción investigativa científica y disciplinaria en cuanto transferencia tecnológica; sin embargo, prescindir de la generación pedagógico-didáctica vía investigación educativa, de fórmulas de aprendizaje localmente situadas, no puede seguir quedando de lado ya que es un tema que no se puede exportar por vía alguna.

Básicamente, la innovación educativa representa hoy, para nuestras universidades y sus cuerpos colegiados incluyendo estudiantes, un mecanismo para mostrar con publicaciones científicas, con libros académicos y con guías educativas, el potencial creativo de nuestros claustros y de sus alumnados, en el marco del proceso de enseñanza-aprendizaje.

Con los GIE, el aula se convierte en el laboratorio vivo de experimentación educacional, no hay posibilidad para negar una u otra práctica, siempre y cuando éstas se encuentren enmarcadas en los cánones de la ética y el respeto a la persona, por lo demás, los elementos del llamado 
diamante curricular: contenidos, objetivos, métodos, secuencias, recursos, procesos evaluativos son manipulables, mejorables y por supuesto, susceptibles de innovación con el fin de apuntar a mejores trayectorias educativas que integran el acceso equitativo, la permanencia y el egreso exitoso del alumnado.

Las ayudantías de investigación, tan cotizadas para alcanzar los propósitos científicos y, tan difíciles de costear en los modelos de investigación científica disciplinar, en los GIE resulta de natural presencia, pues son los propios estudiantes los que mediante mecanismos de investigación-acción se presentan como corresponsables de la intervención educativa, así, ya no se cuenta con un solo ayudante sino con todo un equipo llamado -aula- que busca desde su accionar innovador alcanzar los resultados más propicios, lo que luego se verá revelado en la estadística de apropiación de aprendizajes, tasas de inserción, de retención y graduación, según corresponda.

La tendencia natural en una investigación es la de alcanzar los resultados esperados, comprobando para ello, las tesis propuestas; en el caso de los GIE, sus resultados no solo favorecen el ejercicio investigativo del grupo al permitir que sus líneas de intervención sean perdurables en el tiempo, sino que favorecen a la institución educativa como tal. Consideremos los procesos de evaluación y acreditación a las IES, más de un indicador de calidad, sea cual fuere el modelo aplicado, toma en consideración temas de acceso, retención y titulación; por lo señalado, la promoción de los GIE genera pactos colectivos áulicos, cuyos beneficiarios son estudiantes, docentes e instituciones.

Aún es habitual encontrar en las universidades, a aquellos docentes que trabajan en solitario su acción pedagógica, por lo general, este tipo de catedráticos consideran que dicha fórmula les es oportuna, principalmente para proteger sus recursos didácticos que nadie cuestiona, y que les habrá tomado mucho tiempo elaborar, sin embargo, también es común que aquellos 
recursos sean de los menos actualizados.

En contraste a lo anterior, en el espectro de la investigación, es muy inusual encontrar un agente insociable, esto por varios factores como la necesidad del diálogo disciplinar, la tendencia a generar redes, la obvia necesidad de contar con ayudantes y asistentes de investigación para las tareas más operativas, esto dentro de los GIE también es tendencia, permitiendo que el docente pase de la lógica de planificación didáctica unipersonal a otras, donde los equipos docentes se distribuyen esa tarea; en síntesis, un GIE provoca comunión de catedráticos para repensar, entre otras, las fórmulas de aprendizaje cooperativo que lleven a la construcción de recursos compartidos y para generar procesos de evaluación vía proyectos y cátedras integradoras.

Nadie niega que los saberes son universales, pero, así como el proceso de asimilación de aprendizaje es muy particular de cada individuo, aunque para ello se tome carta de propuestas colectivas de construcción de saberes, es necesario volver a recalcar que es posible exportar la ciencia disciplinar y contextualizarla para ofrecerla vía pensum de estudios, pero hacer lo mismo con los métodos de aprendizaje, sus didácticas y fórmulas evaluativas, -no-. Por tanto, paradigmas de educación del primer mundo, efectivos para ellos, no terminan siendo oportunos para nuestros contextos, es necesario construirlos desde nuestra experiencia, con nuestra gente y aplicándolos en nuestros propios campus.

Una pedagogía propia, como la pedagogía de la esperanza de Freire (1993): en la que mencionaba, que "tal vez nunca hayamos tenido en nuestra historia una necesidad tan grande de estudiar, de enseñar, de aprender, como hoy" (pág. 109); se viralizó y fue efectiva en nuestra América, porque fue escrita, trabajada y sistematizada desde nosotros.

No es que neguemos la ciencia pedagógica y didáctica construida hasta ahora y que, principalmente se ha desarrollado bajo las experiencias de 
Europa, las respetamos y agradecemos que hayan sido luz de guía de nuestros pasos educacionales, pero es posible iniciar desde los aportes de la investigación educativa una nueva era pedagógica para nuestras fronteras.

Palabras clave: docente; educación; editorial.

Fecha de Recepción:

07-10-2019
Fecha de Aceptación: 26-12-2019
Fecha de Publicación: 05-02-2020 


\section{GIE Educational Innovation Groups: A valid alternative for University Teachers}

\section{Editorial}

The Higher Education Institutions of Latin America have not necessarily handled a cutting-edge scenario in the processes of scientific research, either because their academic tradition was oriented, especially, to the field of teaching or, because the potential of their cloisters has been underestimated academics to generate knowledge or, even, because of the precarious sources of funding that university projects have supported, so historically, teaching and research extension have been privileged.

However, from the aforementioned, it is still true that, on more than one occasion, the teaching bodies, often alone and with insufficient university management structures, have solved relevant solutions to the challenges that their sociocultural environment has given them known to require the title of the research function. Given the present duality, it is necessary to demystify those logics that privilege the vision that research can only be gestated by those with great disciplinary skills or that is a particular process of those who possess a scientific degree of the highest level.

The various formulas of classification of the investigation give us a first guideline to understand that the generation of pure knowledge is as valid as the application of the current ones; Creation or transfer models are not better or worse, but only based on their results.

On the other hand, it must be understood that the different sciences cover multiple disciplines and then, unidisciplinary research is as timely as that which brings together various epistemic perspectives; also, the classifications by areas, subareas or domains is so wide that it fits all possibilities. Therefore, there is no way to disregard any investigative attempt, it is enough to count, as Bunge (2004) mentions: with a problem that can be treated, that is well formulated, conceived and defined (p. 166). 
It is there, in the research problem, where the different possibilities are nurtured so that university teachers, without exception, consider moving from teachers to teacher-researchers, in that sense, a universal proposal for this would be that the learning problems inherent in the chair assigned to each teacher become the main focus of research.

The approaches to these problems can be extended from: the field of didactics, methodology and learning techniques, evaluation of knowledge and performance, learning sequences, the use of teaching resources including information and communication technologies, in Finally, from each of the components of the so-called curricular diamond, research fields can be offered whose object of study is the improvement of learning. Therefore, educational research is conducive to every teacher, without exception of their level of training or their scientific skills.

Like any process in search of solutions, it must be necessary to correctly consider the research objectives, and in the case of education, these are evident, even more so when social inequalities are decisive in the so-called access, permanence and successful exit formulas that so far are not effective at all in each of the education subsystems including the tertiary. In short, for Pesántez, Martín, Bojorque (2015): it is a vision of equality at the various levels of the school career, together with access to the cultural assets of science, techniques and arts, in order to meet the challenges from higher education, it allows the goals to be achieved to emerge (pp. 63-73).

Therefore, having GI Scientific Research Groups and other so-called GIE Educational Innovation Groups, is not only possible in the university environment, but also necessary to boost educational action, it is even possible to do without the -GI- more not of the so-called GIE, since the first of our beneficiaries to be served in a scientific way must be the student himself, as learning methods that are offered.

The history of the university, at least thus supports it, evidence that for 
decades scientific research was incipient in our America, and the issue of scientific development was resolved with the appropriation of knowledge via text acquisition, training processes abroad and today, with the consideration that knowledge is global and interconnected, scientific and disciplinary research action could be mitigated in some way as a technology transfer; nevertheless, to do without the pedagogical-didactic generation via educational research, of locally located learning formulas, cannot continue to be left aside since it is a subject that cannot be exported by any means.

Basically, educational innovation represents today, for our universities and their collegiate bodies including students, a mechanism to show with scientific publications, with academic books and with educational guides, the creative potential of our cloisters and their students, within the framework of the process Teaching-learning.

With the GIE, the classroom becomes the living laboratory of educational experimentation, there is no possibility to deny one or another practice, as long as these are framed in the canons of ethics and respect for the person, otherwise, The elements of the so-called curricular diamond: content, objectives, methods, sequences, resources, evaluative processes are manipulate, improvable and of course, susceptible to innovation in order to aim at better educational trajectories that integrate equitable access, permanence and discharge student success.

Research assistants, so sought after to achieve scientific purposes and, so difficult to afford in disciplinary scientific research models, in GIE are naturally present, since it is the students themselves who, through action research mechanisms, present themselves as responsible for the educational intervention, thus, there is no longer a single assistant but a whole team called -classroom- that seeks from its innovative actions to achieve the most favorable results, which will then be revealed in the learning appropriation statistics, insertion, retention and graduation rates, as appropriate. 
The natural tendency in an investigation is to achieve the expected results, checking for it, the proposed theses; In the case of the GIE, their results not only favor the research exercise of the group by allowing their lines of intervention to be lasting over time, but they favor the educational institution as such. Consider the processes of evaluation and accreditation of IES, more than one quality indicator, whatever the model applied, it takes into account issues of access, retention and qualification; Therefore, the promotion of the GIE generates collective bargaining agreements, whose beneficiaries are students, teachers and institutions.

It is still customary to find in the universities, those teachers who work alone their pedagogical action, in general, this type of professors consider that this formula is appropriate for them, mainly to protect their teaching resources that nobody questions, and that they will have taken A long time to elaborate, however, it is also common for those resources to be the least updated.

In contrast to the above, in the spectrum of research, it is very unusual to find an unsociable agent, this due to several factors such as the need for disciplinary dialogue, the tendency to generate networks, the obvious need to have research assistants and assistants to the most operational tasks, this within the GIE is also a trend, allowing the teacher to move from the logic of one-person teaching planning to others, where the teaching teams distribute that task; In summary, a GIE provokes fellowship of professors to rethink, among others, the cooperative learning formulas that lead to the construction of shared resources and to generate evaluation processes via projects and integrative chairs.

No one denies that knowledge is universal, but, just as the process of assimilation of learning is very particular for each individual, although for this, a letter of collective proposals for the construction of knowledge is taken, it is necessary to emphasize again that it is possible to export science discipline and contextualize it to offer it via a study plan, but do the same with the learning 
methods, their didactics and evaluative formulas, -not-. Therefore, first-world education paradigms, effective for them, do not end up being appropriate for our contexts, it is necessary to build them from our experience, with our people and applying them on our own campuses.

A pedagogy of our own, like the pedagogy of hope of Freire (1993): in which he mentioned, that "perhaps we have never had in our history such a great need to study, to teach, to learn, as today" (p. 109); It went viral and was effective in our America, because it was written, worked and systematized from us.

It is not that we deny the pedagogical and didactic science built so far and that, mainly it has been developed under the experiences of Europe, we respect them and we appreciate that they have been the guiding light of our educational steps, but it is possible to start from the contributions of research educational a new pedagogical era for our borders.

Keywords: teacher; education; publisher.

Date Received:

07-10-2019
Date Acceptance:

26-12-2019
Date Publication:

05-02-2020 


\section{Referencias}

Bunge, M. (2004). La investigación científica: su estrategia y su filosofía. Tercera edición, ISBN: 968-23-2225-1. México, D.F.: Siglo XXI Editores, S.A. de C.V.

Pesántez, F., Martín, E., \& Bojorque, R. (2015). Una mirada crítica al sistema de acceso a la Educación Superior ecuatoriana. Revista Cubana de Educación Superior, 34(2), 63-76, e-ISSN: 0257-4314. Recuperado de: http://scielo.sld.cu/scielo.php?script=sci arttext\&pid=S0257-

43142015000200007\&lng=es\&tlng=es

Freire, P. (1993). Pedagogía de la esperanza: un reencuentro con la pedagogía del oprimido. Primera edición, ISBN: 968-23.1899-8. México, D.F.: Siglo XXI Editores, S.A. de C.V. 


\section{Lauro Fernando Pesántez Avilés \\ e-mail: fpesantez@ups.edu.ec}

Nacido en Cuenca, Ecuador, el 1 de octubre del año 1972.

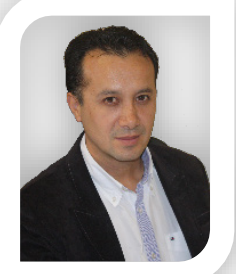

Doctor en Ciencias de la Educación por la Universidad de La Habana (UH), Cuba; Actualmente, Vicerrector General de la Universidad Politécnica Salesiana (UPS); Magíster en Docencia Universitaria, Universidad del Azuay (UDA); Diploma Superior en Evaluación de la Educación Superior, Universidad Politécnica Salesiana (UPS); Magister en Sistemas Integrados en Gestión de la Calidad, Ambiente y Seguridad, Universidad Politécnica Salesiana (UPS); Especialista en Docencia Universitaria, Universidad del Azuay (UDA); Licenciado Ciencias de la Educación, Universidad Politécnica Salesiana (UPS); Ha ejercido diversas funciones, entre ellas, Vicerrector Docente, Vicerrector Académico, Director de Desarrollo Académico, Subdecano de Facultad, Director de Proyectos, Director de Carrera, Docente de grado y postgrado; Autor de varios capítulos de libros y artículos; Investigador principal y alterno; Evaluador de trabajos científicos; entre mi Misión está mejorar los índices de acceso, aprendizaje y participación de poblaciones históricamente excluidas es el eje que fundamenta su quehacer como Director de la Cátedra UNESCO Tecnologías de apoyo para la Inclusión Educativa de la Universidad Politécnica Salesiana (UPS); Grupo de Innovación Educativa Repensando la Educación GIE-RED. 